\title{
Aspects of the Uptake of Dissolved Oxygen in Cabiúnas and Imboassica Lagoons (Macaé, RJ)
}

\author{
Paulo R. Brum ${ }^{1}$, Vinicius F. Farjalla ${ }^{1}$, José F. Gonçalves Jr. ${ }^{1}$, Anderson M. dos Santos ${ }^{1}$, \\ Maurício T. Pôrto ${ }^{1}$, Elisa D. R. Vieira ${ }^{2}$, Flávia M. Ferreira ${ }^{1}$, \& Irineu Bianchini Jr. ${ }^{3}$ \\ ${ }^{1}$ Programa Pós Grad. Ecologia, Instituto de Biologia, Univ. Federal do Rio de Janeiro (UFRJ), Rio de Janeiro, \\ Brasil CEP 21941-590; ${ }^{2}$ PPG Biofísica, Univ. Federal do Rio de Janeiro (UFRJ), Rio de Janeiro, Brasil CEP \\ 21941-590; ${ }^{3}$ PPGERN e Depto. Hidrobiologia, Univ. Federal de São Carlos (UFSCar), São Carlos, São Paulo, \\ Brasil.
}

\begin{abstract}
In this work, we describe qualitative and quantitative aspects of the cycling of detritus of aquatic macrophytes and carbohydrates in two coastal lagoons of the northeastern part of the State of Rio de Janeiro. Samples of water of the Imboassica and Cabiúnas lagoons were enriched with sucrose. Samples of water of the Cabiunas lagoon were also utilized to arrange mineralization chambers with fragments of three species of aquatic macrophytes found in these lagoons (Typha domingensis, Potamogeton stenostachys and Nymphaea ampla). Following that, the bottles were aerated and incubated (in the laboratory) for a period of 8 days. The concentrations of dissolved oxygen, the pH, the electrical conductivity and the temperature were daily measured. The anaerobic processes were inhibited by periodical aeration of the bottles. The results suggested that the mineralization process in Imboassica lagoon was more efficient; in Cabiúnas lagoon the process of immobilization of the organic matter was dominant. In the short term, maximum oxygen uptake occurred in the mineralization of $N$. ampla, followed by the mineralization of $P$. stenostachys and of $T$. domingensis. However, it was estimated that in long term the mineralization of $P$. stenostachys showed a greater oxygen uptake.
\end{abstract}

Key words: decomposition, aerobic mineralization, dissolved oxygen, coastal lagoons, aquatic macrophytes.

\section{INTRODUCTION}

In the aquatic ecosystem, the concentrations of dissolved oxygen are influenced by the chemical and biological processes of oxidation. Related to the concentrations of the reduced compounds, these processes may utilize a great portion of the oxygen reserves of these environments. The biological oxidations occur, basically, through the catabolic processes of the microbial communities, in the processing of detritus (Wetzel, 1983).

The degradation processes occur in aerobic and anaerobic conditions. These conditions promote the differentiation of the microorganisms involved and, therefore, of the gaseous mixtures produced. The selection of microorganisms implicates in the adoption of distinct metabolic routes and not only the gases, but also the products generated are different (Jewell, 1971; Twilley et al, 1986; Gale et al, 1992; Moore Jr. et al, 1992). The aerobic process acts over a broader spectrum of kinds of organic matter. It generates more stable products and a greater number of microbial cells. In environments with low concentrations of organic matter this process is usually fast, efficient and with a low odoriferous potential (Davis \& Cornwell, 1991). Experiments related to the aerobic mineralization have shown that the kinetics of oxygen uptake may reflect qualitative aspects of the detritus, as well as suggesting variation in the stoichiometrics of the processes (Bitar, 1995). Experiments of aerobic mineralization with glucose indicate the reaction coefficients change according to the concentrations of the substrate; they also suggest that the concentrations of the substrate may interfere with the yield of the processes of formation of microbial cells (Bitar \& Bianchini Jr., 1994).

This work aims to compare the oxygen uptake in the mineralization of three species of aquatic macrophytes that are found in the Cabiúnas and Imboassica lagoons. It also aims to establish the 
workability of the experimental procedure of incubations under controlled conditions in limnological studies of coastal lagoons.

\section{MATERIALS AND METHODS}

For the execution of the experiments, we collected samples of water from the Imboassica and Cabiúnas lagoons. Imboassica is located inside the urban perimeter of the municipality of Macaé $\left(23^{\circ} 25^{\prime} \mathrm{S}\right.$ and $23^{\circ} 35^{\prime} \mathrm{S}, 42^{\circ} 35^{\prime} \mathrm{W}$ and $42^{\circ} 45^{\prime} \mathrm{W}$ ), having an area of $3,26 \mathrm{~km}^{2}$ and an elongated shape (Fernandes, 1997). The Cabiúnas lagoons is also located in the municipality of Macaé, however, outside of its urban perimeter $\left(22^{\circ} 16^{\prime} \mathrm{S}, 41^{\circ} 40^{\prime} \mathrm{W}\right)$, having an area of 0,35 $\mathrm{km}^{2}$ (Esteves et al, 1983). In both lagoons, the samples were obtained at two sampling points related to the littoral and pelagial regions. The first experiment was constituted by the incubation (in laboratory) of samples of water enriched with sucrose at a $20 \mathrm{mg} / \mathrm{L}$ concentration (Antonio, 1992). For each sample, three experimental bottles and one control bottle (without the addition of the sugar) were prepared. In the second experiment, dried and ground $\left(\approx 50 \quad{ }^{\circ} \mathrm{C}\right)$ fragments of Typha domingensis, Potamogeton stenostachys and Nymphaea ampla were added to the samples of water (of the littoral region). These species of aquatic macrophytes were previously collected in the littoral region. For each species, three bottles containing fragments of the plant at a concentration of $200 \mathrm{mg} / \mathrm{L}$ were set up; as a control, two bottles containing only water from the littoral region of the lagoon were also set up. After the addition of sucrose or of the plant fragments, the bottles were aerated for $20 \mathrm{~min}$ in order to bring the oxygen concentrations close to the saturation point (Bitar, 1995). After that, in each bottle the $\mathrm{pH}$ and the electrical conductivity were determined. Following this, the bottles were incubated in a box with thermal insulator in dark and bathed with water. For 8 days concentrations of dissolved oxygen, temperature, $\mathrm{pH}$ and electrical conductivity were determined (by potenciometry) daily. The anaerobic processes were inhibited by the reaeration of the flasks, when the oxygen concentrations fell to a level below $4 \mathrm{mg} / \mathrm{L}$.

\section{RESULTS AND DISCUSSION}

Figure 1 presents the average uptakes of oxygen in the bottles with macrophyte fragments (A) and sucrose ( $\mathrm{B}$ and $\mathrm{C}$ ) are presented. Higher uptakes were noted throughout the mineralization of $N$. ampla, closely followed by $P$. stenostachys and $T$. domingensis. Adjusting these results to a kinetic model of $1^{\text {st }}$ order, similar to that adopted in the BOD testing (Davis \& Cromwell, 1991), it was possible to assert that $P$. stenostachys has the highest uptake of oxygen (377 mg of oxygen/g of DW). However, this process presented the smallest coefficient of desoxygenation (half life $\approx 12$ days). The mineralization of the species with floating leaves ( $N$. ampla) exhibited intermediate values of uptake (258 $\mathrm{mg}$ of oxygen $/ \mathrm{g}$ of DW) and coefficient of desoxygenation $\left(\mathrm{k}=0,136 \mathrm{day}^{-1}\right)$. The latter corresponded to a half life $\left(t_{1 / 2}\right)$ of approximately 6 days. The coefficient of mineralization $\left(\mathrm{k}=0,147 \mathrm{day}^{-1}\right)$ of the emergent species ( $T$. domingensis) was 2,7 times greater than the one obtained for $N$. ampla and 1,08 times greater than the one estimated for $P$. stenostachys. However, the mineralization of $T$. domingensis showed the smallest uptake (139 $\mathrm{mg}$ of oxygen/g of DW). These results suggested that the potential for oxygen uptake was related with the composition of the plant tissues. In this context, $T$. domingensis constituted the most refractory resource and $P$. stenostachys was the most labile one, $N$. ampla having an intermediate composition. Therefore, it could be supposed that the mineralization of $T$. domingensis was restricted to the oxidation of the labile and/or leachable portions of this species; probably the protoplasmatic fraction. However, due to the labile character of these fractions, these oxidations occurred under the highest rates. On the other side, the mineralization of $P$. stenostachys probably encompassed a greater fraction of particulate organic matter (POM), reflecting on the diminution of its oxidation coefficient. The incorporation of the POM in the short term mineralization processes of $P$. stenostachys is a consequence of its tender structure, since it is a submersed species, that has no need for support structures. 


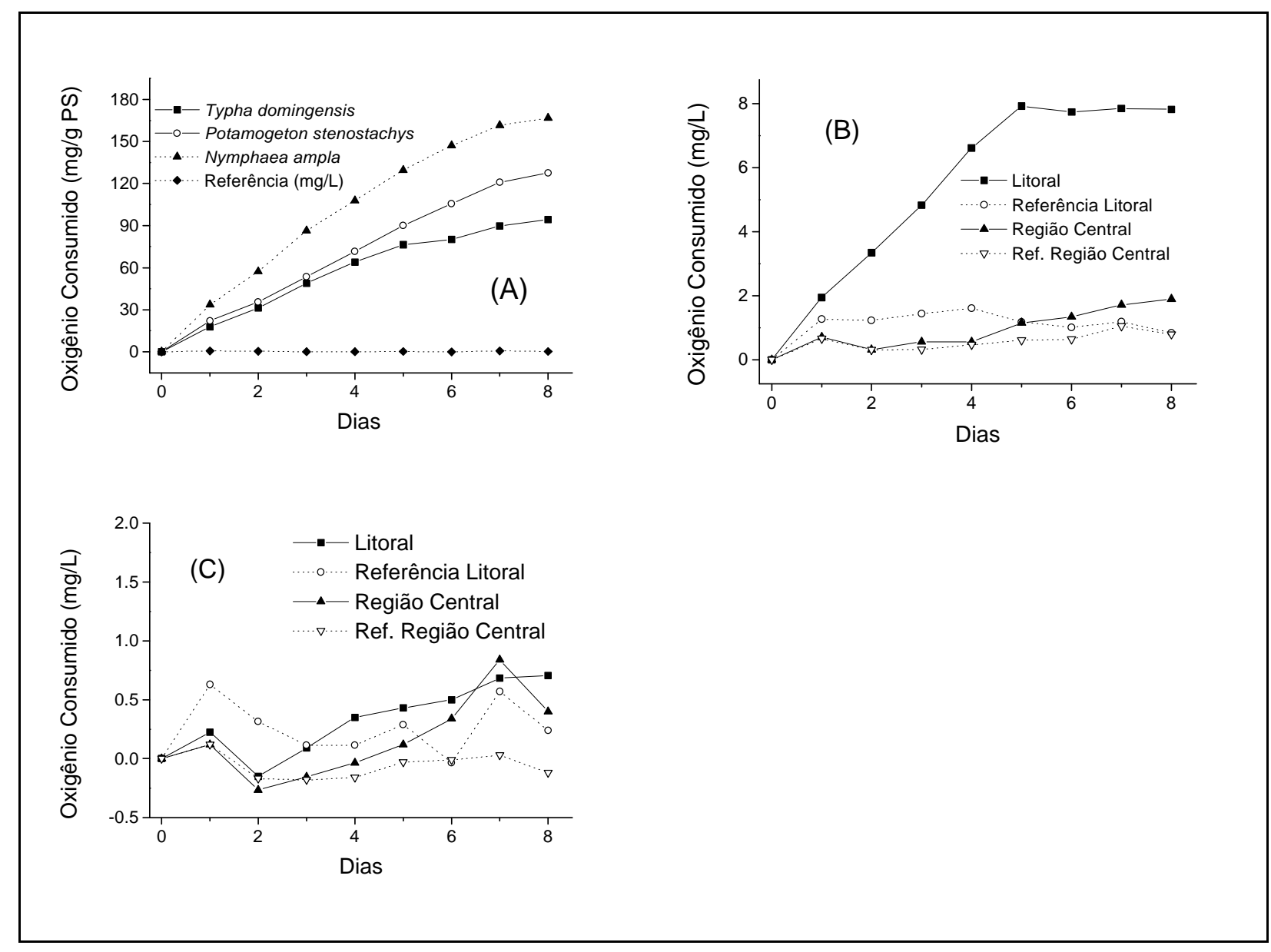

Figure 1. Temporal variations of the dissolved oxygen uptake in the mineralization of the aquatic macrophytes (A) and of sucrose in the samples of water of the Imboassica (B) and Cabiúnas (C) lagoons.

Adopting the stoichiometric relationship of the oxidation of glucose and admitting that these plant have around 45,9\% of carbon (as Typha latifolia, Boyd \& Hess, 1970), through the values of oxygen uptake it was possible to estimate that T. domingensis had approximately $11,2 \%$ of carbon in an easily oxidable form. For $P$. stenostachys this fraction of the carbon corresponded to $30,4 \%$ and for N. ampla, $20,8 \%$. Based on these estimates it was concluded that the processes of short term mineralization involved only a small fraction of the available organic matter, that probably had its main origin in the protoplasm. In this context, it was possible to estimate for these genera, through the decomposition experiments, the following leaching potentials: $50,2 \%$ for Nymphaea (Bianchini Jr., 1982), 12,4\% for Potamogeton (Howard-Williams \& Davies, 1979) and 21,4\% for Typha (Boyd, 1970; Delitti, 1993). Through the estimates for the percentages of labile carbon and of the leaching potentials, it was supposed that in Cabiúnas lagoon, the processes of oxygen uptake from the short term mineralization of the aquatic macrophytes were basically a consequence of the oxidations of the dissolved organic matter. On the other hand, the mineralization of the particulate detritus should generate oxygen demands in the long term and develop with relatively low uptake rates.

From the Figure 1 ( $B$ and $C$ ) it is possible to conclude that: i) the addition of sucrose increased significantly the oxygen uptake in the bottles with samples of water of the littoral region of Imboassica lagoon; ii)however tenuously, the samples enriched with the sugar showed a tendency to exhibited a greater oxygen uptake than the respective controls; iii) the values of oxygen uptake were more enhanced in the bottles with water from the Imboassica lagoon, and iv) the uptakes registered in the 
bottles with water from the littoral and central region of Cabiúnas lagoon were extremely similar.

With the exception of the observation made in the bottles with water from the littoral region of Imboassica lagoon, these results allowed us to suppose that the sugar added was used mainly in the production of microbial cells and/or the formation of refractory compounds (humic substances), instead of being used for energetic purposes. It could be possible that by receiving constant emissions of domestic sewage, the samples of water from the littoral region of Imboassica lagoon contained a greater number of microorganisms, the populations that were more adapted for the consumption of organic matter and the most favorable nutritional conditions for the development of the metabolic processes. Probably, the greater uptakes registered in these samples reflected the synergy of these factors. Discounting the values of uptake related to the mineralization of the organic matter of the control bottles, and considering the stoichiometry of the oxidation of the sucrose, it was estimated that the bottles with water from the littoral region of Imboassica lagoons had around 52\% of the added carbon oxidized, with the remaining (48\%) supporting the production of cells and humic compounds. Comparing these results with those obtained in a similar experiment (Antonio, 1992), which also evaluated the decay of carbohydrates, it was concluded that the percentage allocated for obtaining the energy of this sample (52\%) was approximately 2,7 times higher than the one obtained in samples of water of a marginal lagoon in the Mogi-Guaçu River (Lagoa do Infernão, SP).

Regarding the higher values of oxygen uptake observed in the samples from the Imboassica lagoon, compared with those from Cabiúnas lagoon, as mentioned, it is assumed that the anthropic pressures end up determining the presence of a microbial community that is more adapted to the degradation of organic compounds, as well as the occurrence of a greater availability of organic carbon and nutrients. However, in the Cabiúnas lagoon it must also be considered that besides the smaller anthropic influence over this system, its waters are dark, indicating the abundant presence of humic compounds. In this case, it is possible that these substances may have been attached to the added carbohydrate, making it unavailable to the microorganisms. These results showed the possibility of using incubations of these materials to compare the efficiencies of the cycling of organic matter of different aquatic systems.

In Figure 2, the temporal variation of $\mathrm{pH}$ that occurred due to the mineralization of the macrophytes (A) and of the sucrose (B and C) are presented. In this figure, the variation of the temperature throughout the experiment (D) can be seen. From the beginning until the first day of the experiment, there was a decrease of approximately $3{ }^{\circ} \mathrm{C}$. After that, the temperature oscillated between 20,5 and $22{ }^{\circ} \mathrm{C}$ until the end of the observation period. On average, the experiment developed under the temperature of $21,6 \pm 0,16^{\circ} \mathrm{C}$. Comparing these values with the ones registered in field inventories (Esteves et al., 1983; Fernandes, 1997) it was concluded that the temperature in the experiment oscillated in a range that was compatible with the one observed in the lagoons, not being, therefore, a limiting factor in the mineralization processes.

The values of $\mathrm{pH}$ showed a tendency to decrease in all experimental conditions. Probably these results were due to the generation of $\mathrm{CO}_{2}$ in the bottles, from the processes of mineralization of the organic matter that was originally in the samples, of the sugar, or the aquatic macrophytes' detritus that were added. Lowering of the $\mathrm{pH}$ was attributed to the leaching of the reduced (organic and inorganic) compounds from the decomposition (Bianchini Jr. \& Toledo, 1988). In this context, it may be underlined that in the bottles containing $N$. ampla (the species with the highest leaching potential, Bianchini Jr. (1982)) were the ones where the acidulation was higher (Fig. 2A). With the exception of the control bottle, where the acidulation was gradual, the bottles with aquatic macrophytes' detritus had very fast acidulation from the beginning of the experiment until the first day; after that the values of $\mathrm{pH}$ oscillated between 6 and 6,5. It must be noted that the $\mathrm{pH}$ of the control bottle always oscillated between higher values (Fig. 2A). 

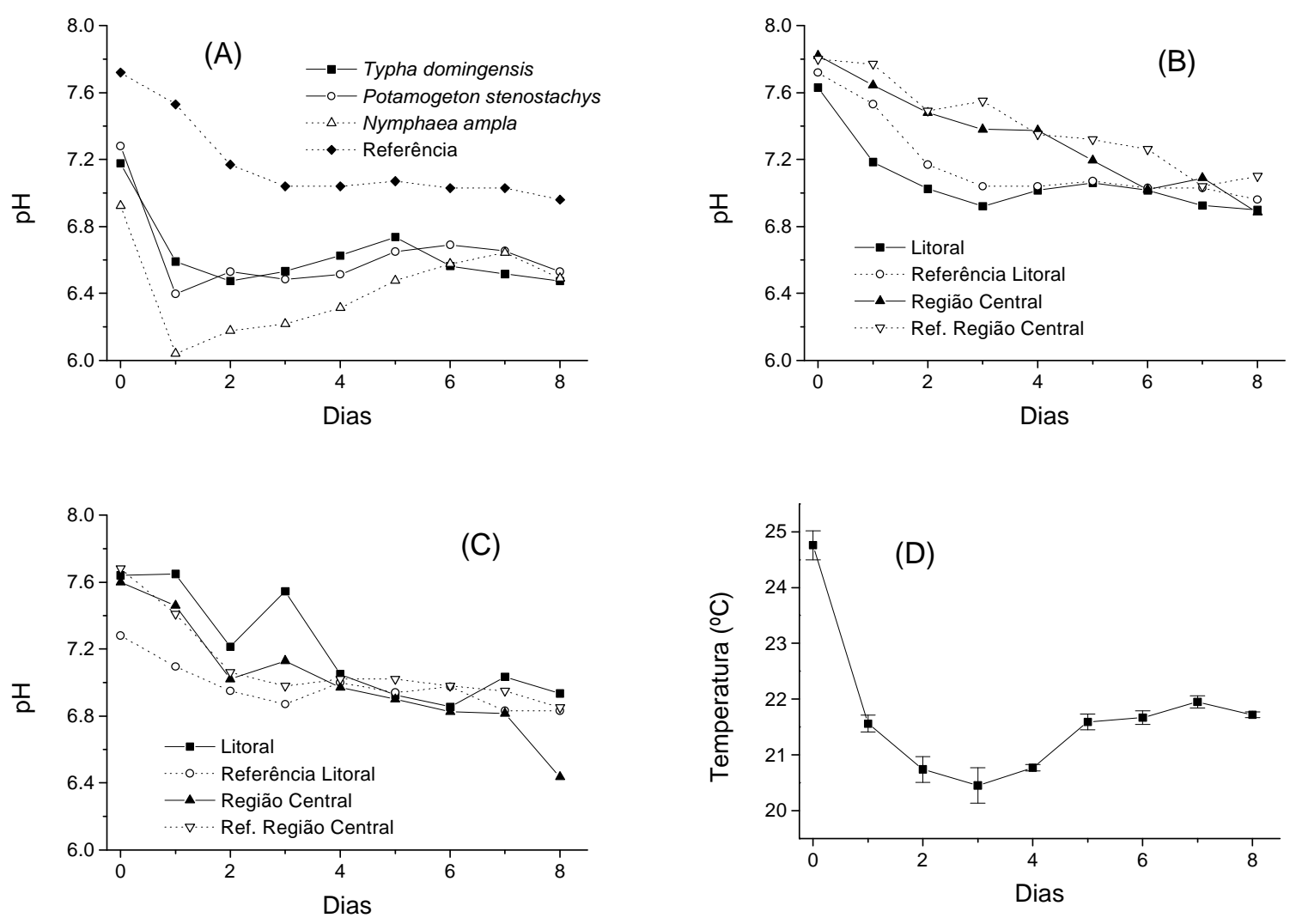

Figure 2. Temporal variations of the $\mathrm{pH}$ through the mineralization of the aquatic macrophytes (A) and of sucrose in the samples of water of the Imboassica (B) and Cabiúnas (C) lagoons. Variation of the temperature in the bottles throughout the experiment.

Probably due to the absence of sucrose, which in fact constituted a supplementary source of $\mathrm{CO}_{2}$, in the samples of Imboassica lagoon, the control bottles always presented higher values of $\mathrm{pH}$. The samples of the littoral region of this lagoon were almost always more acidic than those from the limnetic region. As supposed for the oxygen uptake, these results indicated that the sewage dumping promoted a greater support for the development of microorganisms, and consequently, the lower values of $\mathrm{pH}$ (Figure 2B). It was supposed that by having a tendency to promote more efficiently the immobilization processes, when compared to the mineralization processes, the samples from Cabiúnas lagoon did not exhibit marked differences of $\mathrm{pH}$ related to the enrichment or to the sampling point. Another possibility could be related with the humic compounds present in these samples, which may have had an influence in the buffering of these environments (Figure 2C).
From the difference of the values of electrical conductivity of the control bottles, it was possible to verify the release of electrolytes (total inorganic compounds), by means of the leaching process and, also, the effects of the dissociation of the carbonic acid originated in the catabolism of the labile fractions of the macrophytes' detritus. It was concluded that regarding total electrolytes, there was an intense liberation/formation in the flasks containing $P$. stenostachys and T. domingensis. The mineralization of $N$. ampla generated the smallest concentrations. It could be possible that the smallest contents of inorganic compounds in the bottles with $N$. ampla were due to the greater microbial activity, since, due to the leaching potential in this detritus, it would be expected to find a higher amount of electrolytes in these flasks. Generally speaking, these results indicated the occurrence of intense formation/liberation of electrolytes from the 
setting up of the bottles until the $5^{\text {th }}$ day. From then on, the assimilation (microbial cell production, chemical interactions) processes began to dominate (Figure 3A). Usually, the temporal variations of the electrical conductivity followed those of temperature, however it was possible to verify that in the samples of water of both lagoons the additions of sucrose did not promote marked alterations of this variable. With the exception of the samples of the littoral region of Cabiúnas lagoon, where the enrichment with sucrose was reflected on an increase in the conductivity values. In this case, based on the low oxygen uptake as seen in these bottles (Figure 1C), it was supposed that the values of conductivity presented an increase mainly due to the alteration of the balance of adsorption among the humic compounds and the ions after the enrichment with sucrose. This did not rule out an increase in the electrical conductivity from the biological oxidations. However, it was possible that the oxidations have contributed to this.

\section{CONCLUSIONS}

Based on the experimental procedures adopted it could be concluded that: i) in the short term mineralization processes, the "floating leaves" macrophyte species (N. ampla) was the resource that generated the greater uptake of oxygen, followed by the submersed (P. stenostachys) and emergent ( $T$. domingensis); ii) in the long term degradation, potentially, $P$. stenostachys was the resource that exhibited the greatest uptake of oxygen, $N$. ampla occupied an intermediate position and $T$. domingensis showed to be the most refractory resource; iii) the addition of sucrose in the samples of water of the two lagoons generated tendencies of increasing the oxygen uptake, the electrolyte concentrations and decreasing the $\mathrm{pH}$ values; iv) from the sugar enrichments, in the samples of water of the Imboassica lagoon, there was a tendency towards mineralization, while in the samples of the Cabiúnas lagoon, there was a dominance of immobilization (chemical and/or biological).

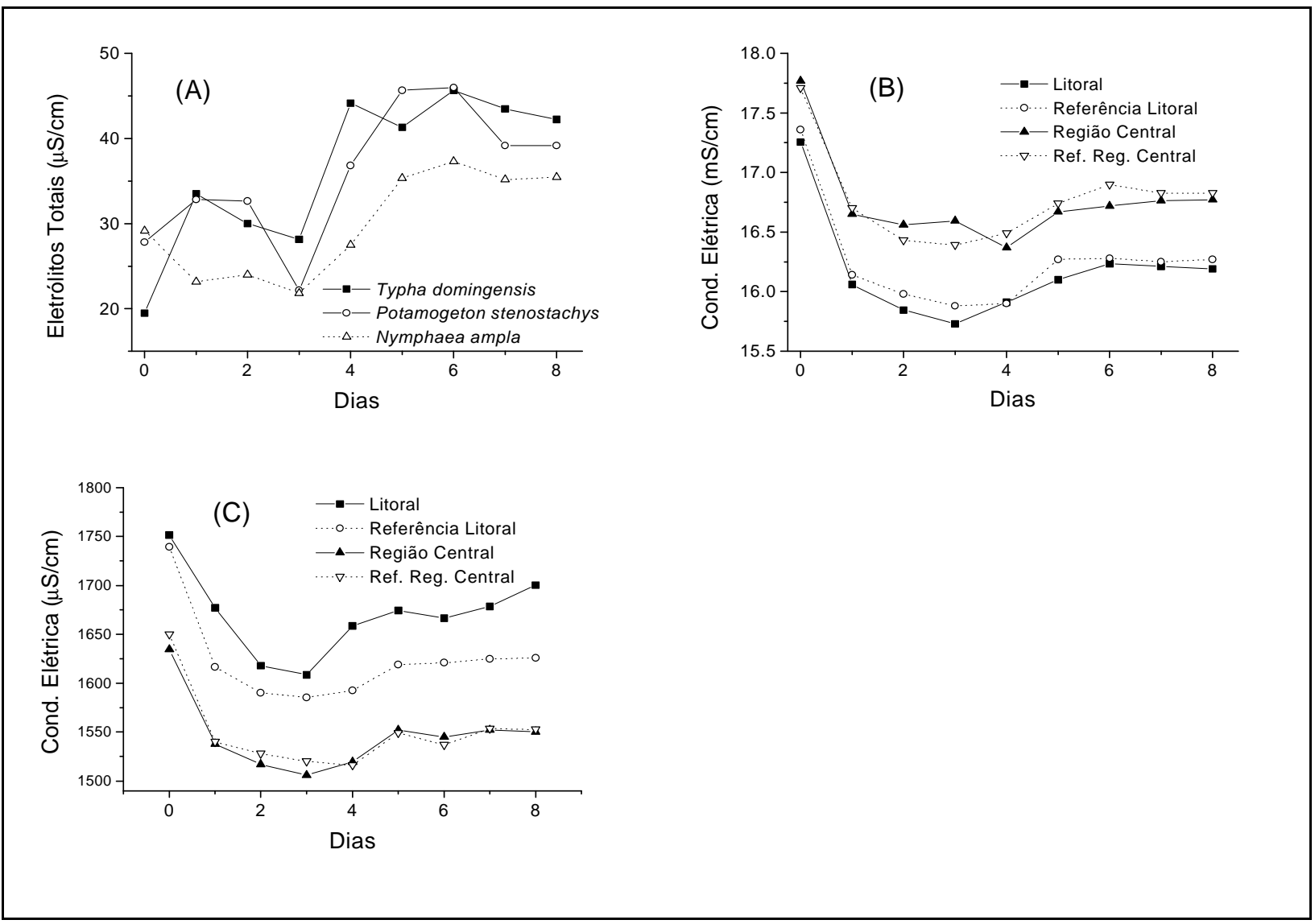

Figure 3. Temporal variation of the electrolytes through the mineralization of the aquatic macrophytes (A) and of the electrical conductivity in the samples of water of the Imboassica (B) and Cabiúnas (C) lagoons. 


\section{RESUMO}

Nesta pesquisa, descrevemos aspectos qualitativos e quantitativos da ciclagem de detritos de macrófitas aquáticas e carboidratos em duas lagoas costeiras do nordeste do Estado do Rio de Janeiro. Amostras de água das lagoas Imboassica e Cabiúnas foram enriquecidas com sacarose. Amostras de água da lagoa Cabiúnas foram também utilizadas para a montagem de câmaras de mineralização com fragmentos de três espécies de macrófitas aquáticas encontradas nestas lagoas (Typha domingensis, Potamogeton stenostachys e Nymphaea ampla). Em seguida, as garrafas foram aeradas e incubadas (no laboratório) por um período de 8 dias. As concentrações de oxigênio dissolvido, o $\mathrm{pH}$, a condutividade elétrica e a temperatura foram medidos diariamente. Os processos anaeróbicos foram inibidos pela aeração periódica das garrafas. Os resultados sugerem que o processo de mineralização na lagoa Imboassica foi mais eficiente; na lagoa Cabiúnas o processo de imobilização da matéria orgânica foi dominante. No curto prazo, o maior consumo de oxigênio ocorreu na mineralização de $N$. ampla, seguida pela mineralização de $P$. stenostachys e de T. domingensis. Entretanto, foi estimado que no longo prazo a mineralização de $P$. stenostachys consumiria uma quantidade maior de oxigênio.

\section{ACKNOWLEDGMENTS}

The authors wish to thank Prof. Dr. Francisco de Assis Esteves for the opportunity of achieving this work and PETROBRAS and CNPq for the financial support.

\section{REFERENCES}

Antonio, R. M. (1996), Estimativa da Capacidade Heterotrófica de Ecossistemas Aquáticos. São Carlos (SP), Depto. Hidrobiologia-UFSCar, 30pp. (Monografia).

Antonio, R. M. (1996), Estimativa da Capacidade Heterotrófica do Lago Infernão (Estação Ecológica de Jataí, SP). São Carlos (SP), PPGERN-UFSCar, 82pp. (Dissertação).
Bianchini Jr., I. \& Toledo, A. P. P. (1988), Decomposição de macrófitas aquáticas: Estudo da variação do $\mathrm{pH}$ e densidade óptica, sob diferentes condições de atmosfera e luminosidade. Anais V Sem. Reg. Ecol. São Carlos: UFSCar, p. 167-181.

Bianchini Jr., I. (1982), Contribuição ao Estudo da Decomposição de Plantas Aquáticas. São Carlos (SP), PPGERN-UFSCar, 178pp. (Dissertação).

Bianchini Jr., I.; Antonio, R. M. \& de Moura L. F. (1997), On the manometric method for estimating the anaerobic mineralization in aquatic ecosystems: kinetic and methodological aspects. Rev. de Microbiol., 28 (1): 83-90.

Bitar, A. L. \& Bianchini Jr., I. (1994), Efeito do teor de matéria orgânica dissolvida sobre as taxas de seu processo de mineralização. In: Anais do I Seminário: Qualidade de Águas Continentais no MERCOSUL. Porto Alegre: UFRS, 311-329.

Bitar, A. L. (1995), Contribuição para o Estudo dos Processos de Mineralização em Sistemas Aquáticos. São Carlos (SP), Depto. Hidrobiologia-UFSCar, 46pp. (Monografia).

Boyd, C. E. \& Hess, L. W. (1970), Factors influencing shoot production and mineral nutrient levels in Typha latifolia. Ecol., 51(2): 296-300.

Boyd, C. E. (1970), Losses of mineral nutrients during decomposition of Typha latifolia. Arch. Hydrobiol., 66: 511-517.

Davis, M. L. \& Cornwell, D. A. (1991),Introduction to Environmental Engineering. New York: McGraw-Hill., 1991.

Delitti, W. B. C. (1993) Decomposição de materiais biológicos em ambiente aquático. São Paulo (SP), THEMAG Engenharia. (relatório técnico).

Esteves, F. A.; Barbieri, R.; Ishii, I. H. \& Camargo, A. F. M. (1983) Estudos limnológicos em algumas lagoas costeiras do Estado do Rio de Janeiro. In: Anais III Sem. Reg. Ecol. São Carlos: UFSCar, 25-38.

Fernandes, V. O. (1997), Variação Temporal da Estrutura e Dinâmica da Comunidade Perifítica, em Dois Tipos de Substrato, na Lagoa Imboacica, Macaé (RJ). São Carlos (SP), PPGERN-UFSCar, 208pp. (Tese de Doutorado). 
Gale, P. M.; Reddy, K. R. \& Graetz, D. A. (1992), Mineralization of sediment organic matter under anoxic conditions. J. Environ. Qual., 21: 394-400.

Howard-Williams, C. \& Davies B. R. (1979), The rates of dry matter and nutrient loss from decomposing Potamogeton pectinatus in a brackish south-temperate costal lake. Fresh. Biol., 9: 13-21.

Jewell, W. J. (1971), Aquatic weed decay: dissolved oxygen utilization and nitrogen and phosphorus regeneration. J. Wat. Poll. Contr. Fed., 43: 1457-1467.

Moore Jr., P. A.; Reddy, K. R. \& Graetz, D. A. (1992), Nutrient transformations in sediments influenced by oxygen supply. J. Environ. Qual., 21: 387-393.

Twilley, R. R.; Ejdung, G.; Romare, P. \& Kemp, W. M. (1985), A comparative study of decomposition and nutrient release for selected aquatic plants occurring in an estuarine environment. Oikos, 47: 190-198.

Wetzel, R. G. (1983), Limnology, 2nd edn. Saunders College, Philadelphia, PA, 860pp.

Received: September 14, 1998; Revised: September 28, 1998; Accepted: February 19, 1999. 